\title{
A CONCISE REVIEW OF COGNITIVE DISSONANCE IN MARKETING IN THE 21ST CENTURY AND POSSIBLE OPPORTUNITIES FOR DEVELOPMENT
}

Rodolfo Henrique Cerbaro ${ }^{1}$ André Da Silva Pereira ${ }^{1}$

Cassiana Maris Lima Cruz ${ }^{1}$ 


\title{
A CONCISE REVIEW OF COGNITIVE DISSONANCE IN MARKETING IN THE 21ST CENTURY AND POSSIBLE OPPORTUNITIES FOR DEVELOPMENT
}

\begin{abstract}
The theory of cognitive dissonance has found several applications in a diverse array of fields, which includes the practice of marketing. The utility in marketing appears toward some topics, including consumer behavior and marketing strategy. The main goal of cognitive dissonance in marketing is, through better understanding of the human psyche and behavior, finding manners of using such knowledge toward improving the defined intents of the field. Here we provide a review of how the cognitive dissonance theory affected marketing throughout the 21 st century and attempt to visualize ways it can move forward, generating new developments for the intertwinement of the two subjects. The expected result is informing the reader of the state of the art of the subjects taken together in the twentieth-first century and hoping to generate possible insights for further work in the field.
\end{abstract}

\section{Key-words: Cognitive Dissonance. Marketing. Opportunities. 21st Century}

\section{Introduction}

How have marketing and the theory of cognitive dissonance intertwined in the twentieth-first century? What further developments the trends allow us to expect? Both questions require delving into the literature to find where the themes come together. After this endeavor, it is possible to indulge in the exercise of attempting to see what one could expect of the relation of the subjects in the years to come and the possible insights that may come into fruition.

The interest in cognitive dissonance has had its boom and busts, with renewed interest appearing by the end of the century (Harmon Jones \& Mills, 1999). Towards marketing, studies are happening nearly since the founding of the theory by Festinger (1957), with examples such as Holloway (1967), Oshikawa (1972) and Connole, Benson e Khera (1977). The literature of marketing did not take long to realize the potential utility of cognitive dissonance in topics the field must tackle to progress, however the study still finds itself somewhat fragmented, with articles handling diverse topics, but no account seems to provide an overview of trends and possible developments. Our goal, therefore, is to handle this existing gap and answering the questions. It should be understood, however, that the gap can prove fructiferous or not, but despite that it is useful to utilize efforts towards gaps in general, as in research one does not know what one may find, as well stipulated by the fact that research faces uncertainty:

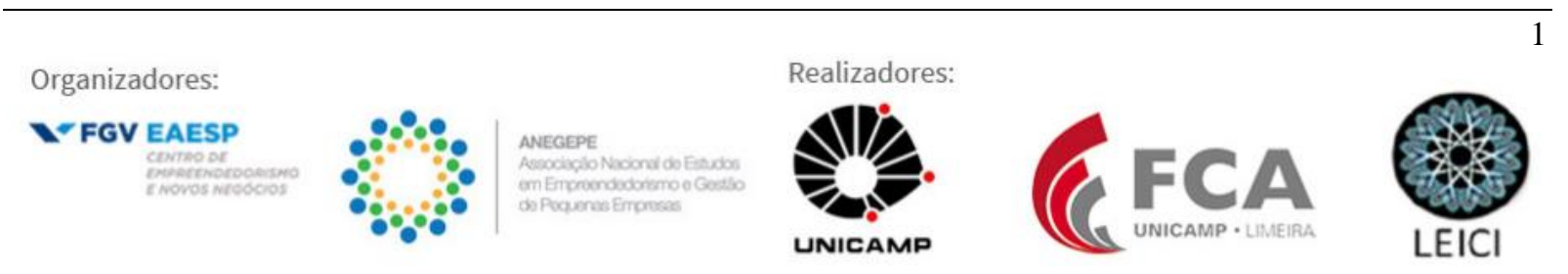


$\mathrm{R}$ and $\mathrm{D}$ management, by its very nature, is characterized by uncertainty since effective $\mathrm{R}$ and $\mathrm{D}$ requires a complex interaction of variables. It is important to balance strategic management (allocate resources and do the right $\mathrm{R}$ and $\mathrm{D}$ ) with operational management (execution of projects) and at the same time take into account issues of people management (leadership, motivation, organization and teamwork) (Doctor, Newton, Person, 2001)

Therefore, it is important to note from the get go that our findings are mostly negative, in the sense that it is difficult to see several trends. Although such is unfortunate, we believe the paper still contributes to the literature in the sense of clarifying how the research in cognitive dissonance stands. The paper utilizes bibliography found in the databases of Scopus and Web of Science, from the beginning of the 21st century onwards. The period encompasses the twentieth-first century threshold of the theory of cognitive dissonance and marketing until November of 2017, providing a timespan that allows for visualization of trends and developments. It is structured in two main themes, the first being the outlining of the literature and the second the analysis undertaken.

\section{Cognitive Dissonance Theory: A Multidisciplinary Resource}

Cognitive dissonance is a theory whose main premise is not complex nor difficult to understand. The premise stands as "individuals dislike inconsistency between cognitions and have a tendency do try to resolve them" (Festinger, 1957), known as the principle of cognitive consistency. The theory was formulated as:

\footnotetext{
"Arising out of a participant observation study of a cult which believed that the earth was going to be destroyed by a flood, and what happened to its members particularly the really committed ones who had given up their homes and jobs to work or the cult — when the flood did not happen. While fringe members were more inclined to recognize that they had made fools of themselves and to "put it down to experience," committed members were more likely to re-interpret the evidence to show that they were right all along (the earth was not destroyed because of the faithfulness of the cult members)." (McLeod, 2014)
}

That is an example, but cognitive dissonance arose applicable to wide range of scenarios, since the premises were not context-dependent enough to warrant specificity. Cognitive dissonance being a psychological notion, however, it has found discord among scholars regarding its falsifiability, according to Karl Popper's (1959) criteria, as one can just say that when the theory does not predict situations, it happens as a motive of the dissonance not being strong enough. Although such difficulties remain and do not seem to have a definitive solution soon, the theory itself appears to have been upheld by many researchers, judging by the number of documents in which the term "cognitive dissonance" is found in databases such as Scopus, when the option all fields is selected, in the dozens of thousands.

The present work assumes the reader is familiar with the main notions of the theory, which derive from the main premise previous. Most of the content of the seminal work by Leon Festinger focused on how to apply the theory, given the relative simplicity of it. Although simple by the standard of most theories, it permeates diverse areas, which study the way the human psyche functions in many different scenarios. Business and marketing as
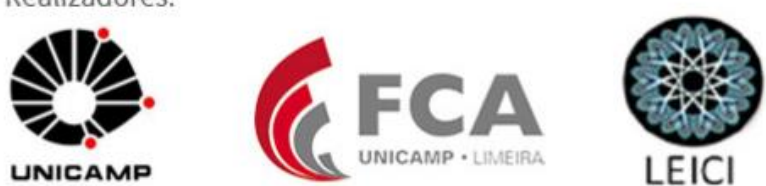
applied social sciences handle human behavior in all its totality and complexity, therefore the theory finds applicability in the fields. Once this is given, the question becomes in which ways it becomes used.

\section{Marketing and Cognitive Dissonance: Method}

Leon Festinger's founding of cognitive dissonance theory is published 1957 and from that time onwards there has been a plethora of works handling the psychological theory. A search for "Article Title, Abstract, Keywords" on Scopus with the input "Cognitive Dissonance" yields 2,436 document results as of 11-28-2017, on Web of Science the correspondent research, which is called by "Topic", yields in the same date 1,836 documents. What one concludes from such is that interest in cognitive dissonance has not been too low in total numbers. When one searches for the categories, business and economics are amongst the top five with the most articles in both Scopus and Web of Science. From such data, one concludes that there has been deemed by researchers that the field of business, which has as a subfield marketing, can utilize insights from the psychological theory of dissonance to handle problems which may appear.

When the search becomes "Cognitive Dissonance", "Marketing", separated by the Boolean operator "AND", the results diminish significantly, to 42 results on Scopus and 87 results on Web of Science. Except for a few false positives, this sample is the main data for the purposes of this paper. If, however, the option of "all fields" is set in place on Scopus, the number of articles rises to 4,135 documents as of 11-30-2017. The criteria here should not be as rigid as to only use the results of 42 and 87 nor too brand as of use all the articles found when the option of all fields is in place. Relevance and discretion in choosing the papers are necessary to fulfill the intentions of the work

\section{Marketing and Cognitive Dissonance: Trends of Research}

Soutar and Sweeney (2003) have considered that although the theory is pervasive in marketing, it has been under-researched. Based on the present research, this premise holds true more than ten years after being written, because although research is significant in cognitive dissonance, in marketing it is still incipient, as the findings here seem to indicate.

Purchase intention/consumer behavior is the most common (and arguably the unique) trend found in articles, totaling 8 articles of the 22 in the section of business found on Scopus and 5 articles of the business category on Web of Science, which intertwine cognitive dissonance and marketing. This is unsurprising, given the goals of marketing and the way dissonance takes part in what is amongst the most important topics of the field, namely the distinct kinds of behavior preceding or succeeding purchase or consumption. However, it is also a sign that raises worries, as the theory has not permeated deeply into various aspects of marketing much thus far in this century.

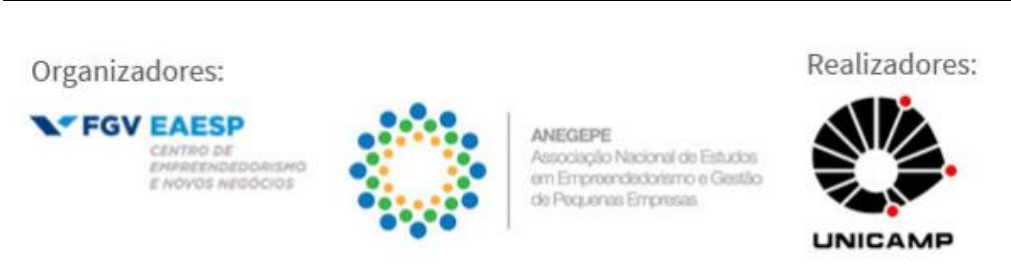


Chart I: Purchase Intention/Consumer Behavior on Scopus

\begin{tabular}{|c|c|c|c|}
\hline Title & Authors & Year & Source \\
\hline $\begin{array}{l}\text { Why do online tourists } \\
\text { need sellers' ratings? } \\
\text { Exploration of the factors } \\
\text { affecting regretful tourist } \\
\text { e-satisfaction }\end{array}$ & Tseng, A & 2017 & $\begin{array}{c}\text { Tourism } \\
\text { Management 59, } \\
\text { pp. 413-424 }\end{array}$ \\
\hline $\begin{array}{l}\text { Country-of-origin } \\
\text { misclassification } \\
\text { awareness and } \\
\text { consumers' behavioral } \\
\text { intentions: Moderating } \\
\text { roles of consumer } \\
\text { affinity, animosity, and } \\
\text { product knowledge }\end{array}$ & Cakici, N.M., Shukla, P. & 2017 & $\begin{array}{l}\text { International } \\
\text { Marketing } \\
\text { Review } \\
\text { 34(3), pp. 354- } \\
376\end{array}$ \\
\hline $\begin{array}{l}\text { Bangladeshi consumers' } \\
\text { purchasing intention } \\
\text { towards organic meat }\end{array}$ & Prince, S.A., Krairit, D. & 2017 & $\begin{array}{c}\text { Journal for } \\
\text { Global Business } \\
\text { Advancement } \\
\text { 10(3), pp. } 305- \\
326\end{array}$ \\
\hline $\begin{array}{l}\text { Flying in the face of } \\
\text { environmental concern: } \\
\text { why green consumers } \\
\text { continue to fly }\end{array}$ & $\begin{array}{l}\text { McDonald, S., Oates, } \\
\text { C.J., Thyne, M., Timmis, } \\
\text { A.J., Carlile, C. }\end{array}$ & 2015 & $\begin{array}{c}\text { Journal of } \\
\text { Marketing } \\
\text { Management } \\
\text { 31(13-14), pp. } \\
\text { 1503-1528 }\end{array}$ \\
\hline
\end{tabular}




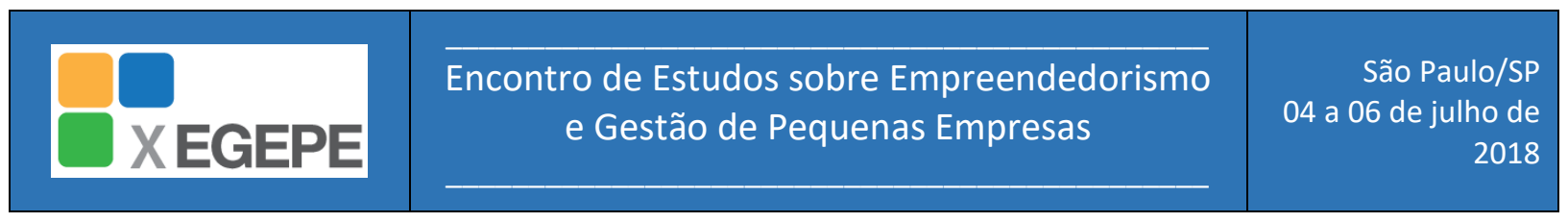

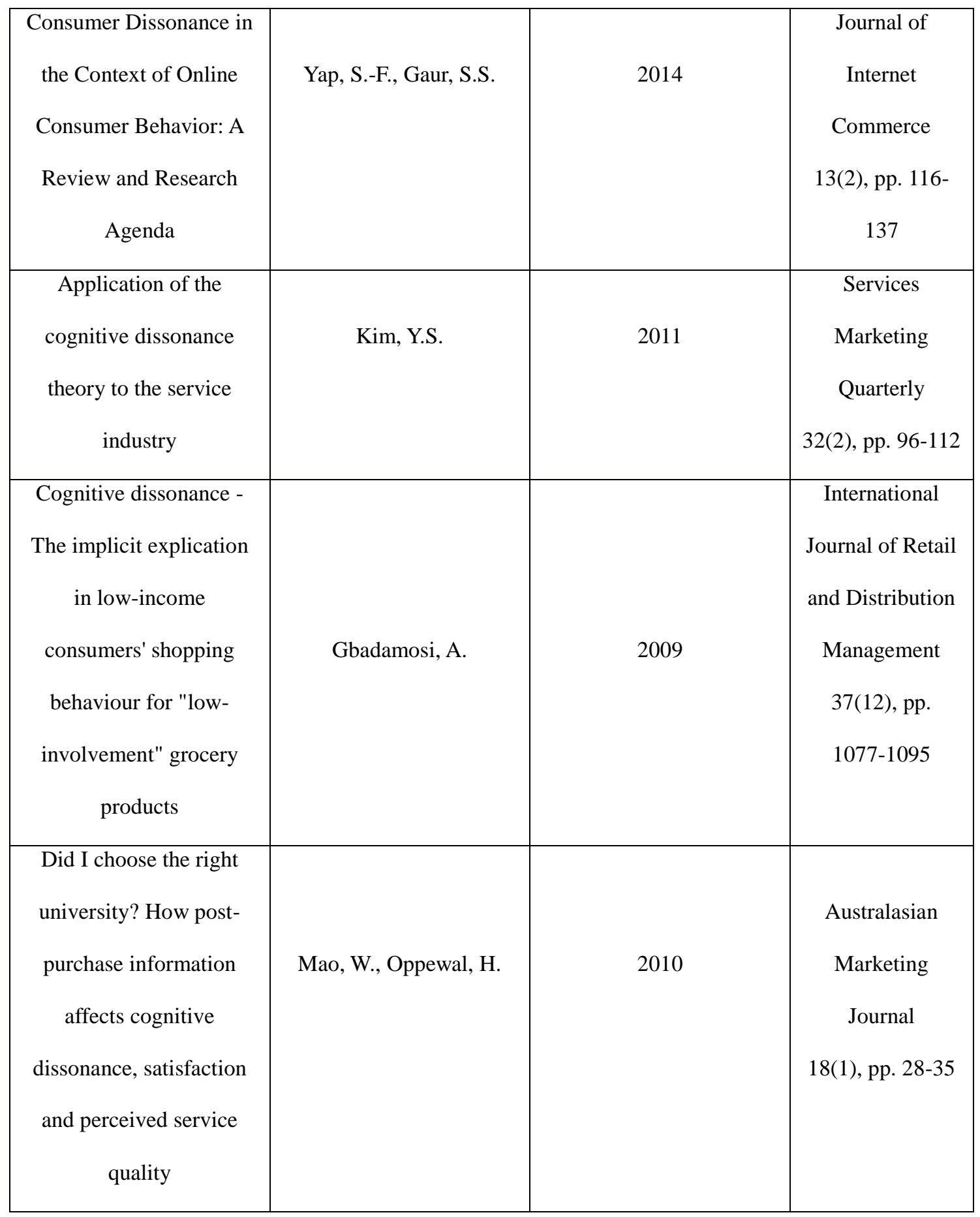

Source: Authors 
Chart 2: Purchase Intention/Consumer Behavior on Web of Science

\begin{tabular}{|c|c|c|c|}
\hline Document Title & Authors & Year & Source \\
\hline $\begin{array}{l}\text { Consumers' behavioural } \\
\text { intentions after } \\
\text { experiencing deception or } \\
\text { cognitive dissonance } \\
\text { caused by deceptive } \\
\text { packaging, package } \\
\text { downsizing or slack } \\
\text { filling }\end{array}$ & $\begin{array}{c}\text { Wilkins, Stephen; } \\
\text { Beckenuyte, Carina; Butt, } \\
\text { Muhammad Mohsin }\end{array}$ & 2016 & $\begin{array}{c}\text { European } \\
\text { Journal of } \\
\text { Marketing 50, } \\
\text { pp. 213-235 }\end{array}$ \\
\hline $\begin{array}{c}\text { Will You Purchase } \\
\text { Environmentally Friendly } \\
\text { Products? Using } \\
\text { Prediction Requests to } \\
\text { Increase Choice of } \\
\text { Sustainable Products }\end{array}$ & $\begin{array}{l}\text { Bodur, H. Onur; Duval, } \\
\text { Kimberly M.; Grohmann, } \\
\text { Bianca. }\end{array}$ & 2015 & $\begin{array}{c}\text { Journal of } \\
\text { Business Ethics, } \\
\text { 129(1), pp. 59- } \\
75\end{array}$ \\
\hline $\begin{array}{l}\text { An Alternative } \\
\text { Explanation of Consumer } \\
\text { Product Returns from the } \\
\text { Postpurchase Dissonance } \\
\text { and Ecological Marketing } \\
\text { Perspectives }\end{array}$ & Lee, Dong Hwan & 2015 & $\begin{array}{l}\text { Psychology \& } \\
\text { Marketing } 32(1) \text {, } \\
\text { pp. 49-64 }\end{array}$ \\
\hline $\begin{array}{c}\text { Beliefs of Chinese buyers } \\
\text { of pirated goods }\end{array}$ & $\begin{array}{l}\text { Stephens, Nancy J.; } \\
\text { Swartz, Teresa A. }\end{array}$ & 2013 & $\begin{array}{c}\text { Journal of } \\
\text { Consumer } \\
\text { Behavior } 12(1) \text {, } \\
\text { pp. } 42-48\end{array}$ \\
\hline
\end{tabular}




\begin{tabular}{|c|c|c|c|}
\hline $\begin{array}{c}\text { Good and Guilt-Free: } \\
\text { The Role of Self- }\end{array}$ & 2013 & Journal of \\
Accountability in & Peloza, John; White, & Marketing 77(1), \\
Influencing Preferences & Katherine; Shang, Jingzhi & & pp. 104-119 \\
for Products with Ethical & & & \\
\hline Attributes & & & \\
\hline
\end{tabular}

Source: Authors

Another subject found in a few articles relates to donation behavior, which may or may not be within consumer behavior, yet it has peculiarities that require caution in classification. Other than that, the trends are difficult to categorize and can be thought of as even inexistent given the small number of articles handling them. Subjects tackled include congruence of impression (Brandon-Lai, S.A., Armstrong, C.G., Ferris, G.R, 2016), influence in religious organization (Chapman, J.R., Westover, J.H., 2015), persuasion of communication (Teng, S., Khong, K.W., Goh, W.W., 2015), relationship marketing (Sharifi, S.S., Esfidani, M.R., 2014), dissonance regarding remuneration (Watson, D; Webb, R; Birdi, A, 2004), for example. It is not possible to infer any trend from such different works.

Marketing is a broad subject and cognitive dissonance has potential to infiltrate in most of the works which by any means involve the human psyche, but the works remain scarce. Why that happens is up for questioning, but the theory is still an interesting framework to use and if there is more knowledge by marketing practitioners that the theory can elucidate subjects faced by them, one can hope the works will appear more often than they have appeared in this period of nearly seventeen years.

\section{Future Developments}

What one concludes from the data is that consumer behavior/purchase intention has been the main theme that relates cognitive dissonance theory and marketing this century so far. Other topics appear, but the whole relation between the two subjects is fragmented and incipient. There is room to develop and advance cognitive dissonance in marketing in any subject of the latter that handles human cognition, and topics that rarely appear such as relationship marketing and strategy of marketing have room to have more thorough and detailed discussions, or, at least, start appearing. It is unfortunate that the theory finds use only toward consumer behavior as a trend in marketing. Noticing how new trends are difficult to come by, because they imply a new way of looking at subjects, Kassem (2011) notes:

"Let's face it. We live in a command-based system, where we have been programmed since our earliest school years to become followers, not individuals. We have been conditioned to embrace teams, the herd, the masses, popular opinion - and to reject what is different, eccentric or stands alone. We are so programmed

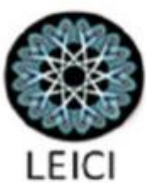


that all it takes for any business or authority to condition our minds to follow or buy something is to simply repeat a statement more than three or four times until we repeat it ourselves and follow it as truth or the best trendiest thing. This is called "programming" -- the frequent repetition of words to condition us how to think, what to like or dislike, and who to follow."

There are difficulties for new developments to appear, one of which is the tendency to keep on the lines of past works, not innovating. That, however, can be changed with efforts by researchers. Also, cognitive dissonance theory is a simple theory that does not require the following of many premises; therefore, one cannot blame the complexity of the theory as a reason for limited application in marketing. Whatever is stopping practitioners from not using the theory requires due diligence in order for the theory to generate interest navigating along the 21 st century.

\section{Conclusion}

The goal of the paper was to attempt to see trends in cognitive dissonance intertwined with marketing in the 21 st century. However, the only trend that repetitively appears is cognitive dissonance applied to consumer behavior. Areas like marketing strategy have no works to speak of, and other themes appear randomly and without posing as real trends. Therefore, we can conclude that, through the bases of Scopus and Web of Science, the main theme researched intertwining cognitive dissonance and marketing is consumer behavior/intention of purchase, with other subjects not much researched and appearing fragmented.

It is arguably unfortunate that the theory has found little research in the timespan specified, but that does not mean it will remain marginalized in the present century. A theory which is both simple and applied in a wide variety of scenarios has room to be further worked on and may allow new insights to be developed, which otherwise, without keeping the theory in mind, would not appear in the intellects of researchers, given it allows for an alternative view of understanding and acting towards the situations reality unveils.

The theory stands as a possible model which can be widely employed (Festinger, 1957), and the more fields and researchers seek to apply it, the better both for the theory as well as for social psychology in general. Marketing has widely benefitted from social psychology theories (Sheth, Parvatiyar, 1995). As a conclusion, therefore, we note that the state of the art as of November 2017, has little trends to show other than consumer behavior/purchase intention, and that there is wide room for expanding the theory of cognitive dissonance deeply in the discipline of marketing. It is our hope that when further literature reviews of the subjects are undertaken, this scenario changes, and the theory receives more attention be it in business administration in general, be it specifically in marketing

\section{References}

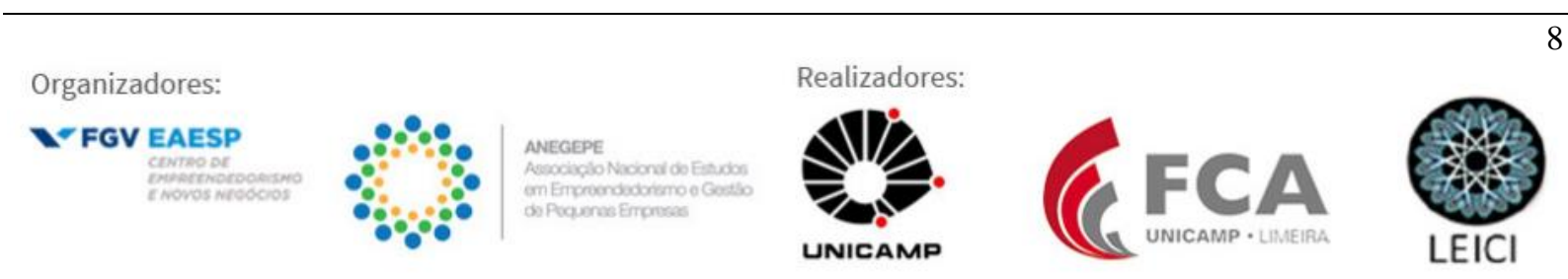


Bodur, H. O., Duval, K. M., \& Grohmann, B. (2015). Will you purchase environmentally friendly products? Using prediction requests to increase choice of sustainable products. Journal of business ethics, 129(1), 59-75.

Brandon-Lai, S. A., Armstrong, C. G., \& Ferris, G. R. (2016). Organisational impression congruence: A conceptual model of multi-level impression management operation in sports service organisations. Sport Management Review, 19(5), 492-505.

Cakici, N. M., Cakici, N. M., Shukla, P., \& Shukla, P. (2017). Country-of-origin misclassification awareness and consumers' behavioral intentions: Moderating roles of consumer affinity, animosity, and product knowledge. International Marketing Review, 34(3), 354-376.

Chapman, Jared R., and Jonathan H. Westover. (2015). "Motivation and Influence within a Religious Organization: A Look at the LDS Church." Organizational Cultures: An International Journal 14 (1): 17-24. doi:10.18848/2327-8013/CGP/v14i01/59258.

Connole, R. J., Benson, J. D., \& Khera, I. P. (1977). Cognitive dissonance among innovators. Journal of the Academy of Marketing Science, 5(1), 9-20.

Doctor, R. N., Newton, D. P., \& Pearson, A. (2001). Managing uncertainty in research and development. Technovation, 21(2), 79-90

Festinger, L. (1957). A theory of cognitive dissonance Evanston. IL: Row, Peterson, 1. 
Gbadamosi, A. (2009). Cognitive dissonance: The implicit explication in low-income consumers' shopping behaviour for "low-involvement" grocery products. International Journal of Retail \& Distribution Management, 37(12), 1077-1095.

Harmon-Jones, E. E., \& Mills, J. E. (1999). Cognitive dissonance: Progress on a pivotal theory in social psychology. In Scientific Conferences Program, 1997, U Texas, Arlington, TX, US; This volume is based on papers presented at a 2-day conference at the University of Texas at Arlington, winter 1997.. American Psychological Association.

Holloway, R. J. (1967). An experiment on consumer dissonance. The Journal of Marketing, $39-43$.

Kassem, S. (2011) Rise up and salute the sun: the writings of Suzy Kassem. Boston, Awakened Press.

Kim, Y. S. (2011). Application of the cognitive dissonance theory to the service industry. Services Marketing Quarterly, 32(2), 96-112.

Lee, D. H. (2015). An alternative explanation of consumer product returns from the postpurchase dissonance and ecological marketing perspectives. Psychology \& Marketing, 32(1), 49-64.

Mao, W., \& Oppewal, H. (2010). Did I choose the right university? How post-purchase information affects cognitive dissonance, satisfaction and perceived service quality. Australasian Marketing Journal (AMJ), 18(1), 28-35. 
McDonald, S., Oates, C. J., Thyne, M., Timmis, A. J., \& Carlile, C. (2015). Flying in the face of environmental concern: why green consumers continue to fly. Journal of Marketing Management, 31(13-14), 1503-1528.

McLeod, S. A. (2014). Cognitive dissonance. Retrieved from www.simplypsychology.org/cognitive-dissonance.html

Oshikawa, S. (1972). The measurement of cognitive dissonance: Some experimental findings. The Journal of Marketing, 64-67.

Peloza, J., White, K., \& Shang, J. (2013). Good and guilt-free: The role of self-accountability in influencing preferences for products with ethical attributes. Journal of Marketing, 77(1), 104-119.

Popper, K. R. (1959). The logic of scientific inquiry. London: Hutchinson.

Prince, S. A., \& Krairit, D. (2017). Bangladeshi consumers' purchasing intention towards organic meat. Journal for Global Business Advancement, 10(3), 305-326.

Shahin Sharifi, S., \& Rahim Esfidani, M. (2014). The impacts of relationship marketing on cognitive dissonance, satisfaction, and loyalty: the mediating role of trust and cognitive dissonance. International Journal of Retail \& Distribution Management, 42(6), 553-575.

Sheth, J. N., \& Parvatiyar, A. (1995). Relationship marketing in consumer markets: antecedents and consequences. Journal of the Academy of marketing Science, 23(4), 255-271. 
Soutar, G. N., \& Sweeney, J. C. (2003). Are there cognitive dissonance segments? Australian Journal of Management, 28(3), 227-249.

Stephens, N. J., \& Swartz, T. A. (2013). Beliefs of Chinese buyers of pirated goods. Journal of Consumer Behaviour, 12(1), 42-48.

Teng, S., Khong, K. W., \& Goh, W. W. (2015). Persuasive communication: A study of major attitude-behavior theories in a social media context. Journal of Internet Commerce, 14(1), 4264.

Tseng, A. (2017). Why do online tourists need sellers' ratings? Exploration of the factors affecting regretful tourist e-satisfaction. Tourism Management, 59, 413-424.

Watson, D., Webb, R. \& Birdi, A. Theor Decis (2004) 57: 367. https://doi.org/10.1007/s11238-005-0121-2

Wilkins, S., Beckenuyte, C., \& Butt, M. M. (2016). Consumers' behavioural intentions after experiencing deception or cognitive dissonance caused by deceptive packaging, package downsizing or slack filling. European Journal of Marketing, 50(1/2), 213-235.

Yap, S. F., \& Gaur, S. S. (2014). Consumer dissonance in the context of online consumer behavior: A review and research agenda. Journal of Internet Commerce, 13(2), 116-137. 